\title{
Spatial and temporal variation in population structure of Hemigrammus marginatus (Characiformes: Characidae) in streams of the Ivinhema River Basin, Brazil
}

\author{
Luzia da Silva Lourenço ${ }^{1,4}$, Izaias Médice Fernandes² \& Yzel Rondon Súarez ${ }^{3}$
}

\author{
${ }_{1}$ Programa de Pós-Graduação em Zoologia, Universidade Estadual Paulista. Caixa Postal 199, 13506-900 Rio Claro, SP, \\ Brazil. \\ 2 Programa de Pós-Graduação em Biologia de Água Doce e Pesca Interior, Instituto Nacional de Pesquisas da Amazônia. \\ Caixa Postal 478, 69011-970 Manaus, AM, Brazil. \\ ${ }^{3}$ Laboratório de Ecologia, Centro Integrado de Análise e Monitoramento Ambiental, Universidade Estadual de Mato Grosso \\ do Sul. Rodovia Dourados-Itahum km 12, 79804-970 Dourados, MS, Brazil. \\ ${ }^{4}$ Corresponding author. E-mail: bioluzia@yahoo.com.br
}

\begin{abstract}
The present study has assessed spatial and temporal variations in the length structure of Hemigrammus marginatus Ellis, 1911 and estimated growth parameters for the species. Sampling was carried out in five streams in the Vitória and Piravevê sub-basins of the Ivinhema River from January to December 2002. A total of 933 specimens of $H$. marginatus were caught (97 in the Vitória sub-basin and 836 in the Piravevê sub-basin). Mean length of the individuals caught in the Piravevê sub-basin was shorter $(21.58 \mathrm{~mm}, \mathrm{SD}=4.67)$ than that of individuals caught in the Vitória subbasin $(29.24 \mathrm{~mm}, \mathrm{SD}=4.42)$. Analysis of condition factor calculated from the weight/length relationship revealed that the values were constant both spatially (between sub-basins) and temporally (throughout the year). In the Piravevê subbasin, the theoretical maximal length estimated for this species was $37.26 \mathrm{~mm}$, with natural mortality rate of 1.22 year $^{-1}$, growth rate (k) of 0.66 year $^{-1}$, and growth performance index ( $\varphi$ ) of 3.80 and 4.25 years of longevity. The input of new individuals in the population occurs twice per year, with greater recruitment at the peak of the rainy season (May) and the peak of the dry season (August).
\end{abstract}

KEY WORDS. Age; growth; mortality; recruitment; weight-length relationship.

All environments are subject to some degree of variation. However, streams historically experience, variations in flow, temperature and oxygen, thus being subjected to more environmental variations than other freshwater environments (Wootтon et al. 2000). Therefore, the life history traits of fishes (i.e., breeding frequency, longevity, age, maximum length, and length at maturation) determine which species persist in a given habitat. Under the prevailing environmental conditions, traits must generate sufficient recruitment for a given population to persist. As a result, stream fishes are particularly adept at responding to local variation. It is due to this that their lifespans are highly variable (GORMAn \& KARR 1978, WOOTTON et al. 2000).

Life-history traits are the underlying determinants of populational responses to environmental forces, and they can differ between populations because of phenotypic plasticity (adaptation to short-term variability of the environment) (NiкоLsky 1963, WootTon 1999). In this context, length structure is particularly important among populations in which growth is flexible, and in which feeding and vulnerability to predation depend on the length of an individual (De Angelis et al. 1993, Wоoтton 1999). Individuals belonging to smaller length classes undergo greater intensity of predation, and are more susceptible to physical and chemical changes in the environment in comparison to larger individuals (REZNICK et al. 1996).

Correctly estimating age and growth of fishes is crucial for effective fishery management. Accurate information on age and growth allows for better understanding of the events in the life history of a given species (GrabowsKi \& Isely 2008). In the Neotropical region, age and growth estimates in small-sized fishes are based on length frequencies, whereas the method based on bone structure remains under-utilized. This is due to the extensive preparation and processing required, as well as lack of infrastructure and appropriate equipment (CAMPANA 2001).

Hemigrammus marginatus Ellis, 1911, is a small characin popularly known in Brazil as "bandeirinha-de-rabo-vermelho". This fish is commonly found in streams and lagoons in the basins of the São Francisco, Paraná and Paraguai rivers (ReIs et al. 2003). Studies on condition factor (Lizama \& Ambrósıo 1999), 
feeding habits (CASATTI et al. 2003) and reproductive dynamics of the species (ANDRADE et al. 2008) have been carried out in the Paraná River Basin. However, no information on population structure, mortality, growth parameters, and recruitment of this species is found in the literature.

Aims of the present study consist of the following: (I) to establish the structure of standard length classes for the Vitoria and Piravevê sub-basins of the Ivinhema River; (II) to analyze the variation in length between the sub-basins; (III) to analyze variation in the length-weight relationship between the subbasins; (IV) to determine whether the condition factor of $H$. marginatus is influenced by temporal (months) and spatial (subbasin) variation; and (V) to estimate growth, mortality and longevity parameters, and recruitment patterns for the Piravevê sub-basin.

\section{MATERIAL AND METHODS}

Sampling was carried out monthly from January to December 2002 in five streams of two sub-basins of the Ivinhema River (three in the Piravevê sub-basin and two in the Vitória sub-basin) (Fig. 1). The Ivinhema is an important tributary of the Upper Paraná River, located in the state of Mato Grosso do Sul, Brazil (Souza-Filho \& Stevaux 2004). Characteristics of the sampled streams (Tab. I) were adapted from Súarez (2008).

In each stream, a stretch of approximately $50 \mathrm{~m}$ was sampled during the day. Sampling was performed using a rectangular sieve with a metal frame $(1.2 \times 0.8 \mathrm{~m})$ and $2-\mathrm{mm}$ mesh size. Twenty deployments were performed in each stretch of stream. The specimens caught were fixed in a $10 \%$ formalin solution and then conserved in 70\% alcohol. They were, identified and deposited at the Museu de Zoologia, Universidade de São Paulo (MZUSP \#80147).

Standard length (SL) was measured in millimeters using a caliper with $0.1 \mathrm{~mm}$ accuracy. Total weight $(\mathrm{Wt})$ in grams was determined using an analytical scale with 0.0001 g precision. Length structure was assessed from the distribution of standard length classes. Two-way analysis of variance (ANOVA) was used to evaluate spatial (sub-basin) and temporal (month) influences over the mean standard length of individuals sampled in the Piravevê and Vitória sub-basins. Weight-length relationship was determined using non-linear regression ad-

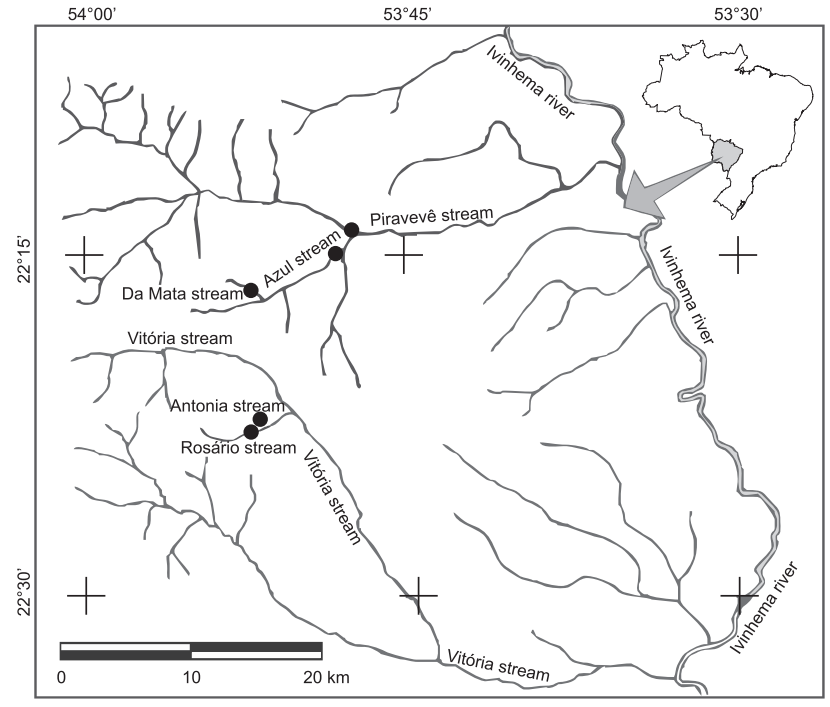

Figure 1. Streams sampled in the Vitória and Piravevê sub-basins of the Ivinhema River Basin, Upper Paraná River, Mato Grosso do Sul, Brazil.

justment and the confidence interval of slope " $\mathrm{b}$ " and intercept "a". Two-way ANOVA was employed to evaluate the influence of temporal and spatial variance over the condition factor (CF), with $\mathrm{CF}$ as the response variable. The sampling month and specific sub-basin served as explanatory variables. CF was calculated as follows: $\mathrm{CF}=$ weight/length ${ }^{\mathrm{b}}$. Weight and length data were previously logarithmically transformed to attend normality and homogeneity of the variances. The KolmogorovSmirnov and Bartlet tests were used to determine normality and homogeneity of the variances, respectively. A 5\% level of significance was set for all statistical tests.

Due to the small number of individuals sampled in the Vitória sub-basin, only specimens sampled in the Piravevê subbasin were used for the analysis of growth, age, mortality and recruitment of $H$. marginatus. Asymptotic length $(\mathrm{L} \infty)$ was estimated from the largest individual in the sample, using Pauly's equation (1983): $\mathrm{L}_{\infty}=\mathrm{L}_{\max } / 0.95$. The growth coefficient (k) was estimated using electronic length-frequency analysis (ELEFAN I method). This method of modal class progression analysis

Table I. General characteristics of sampled streams in the Ivinhema River Basin, Upper Paraná Basin: stream order, water velocity ( $\mathrm{m} / \mathrm{s}$ ), mean water transparency $(m)$, mean depth $(m)$ and mean width $(m)$.

\begin{tabular}{clcccccl}
\hline Sub-basin & Streams & Order & Velocity & Transparency & Depth & Width & Cover \\
\hline Piravevê & Azul & 2 & 0.35 & 0.33 & 0.78 & 3.0 & Without forest, with a lot of grass and Eichhornia azurea along the margin. \\
& Mata & 1 & 0.20 & 0.60 & 0.50 & 1.5 & Channel altered by dam construction, deforestation, and grass along the margin. \\
& Piravevê & 3 & 0.10 & 0.25 & 2.50 & 8.0 & $\begin{array}{l}\text { Forest and grass along the margin, channel with riffles alternating with pools and a } \\
\text { small marginal lagoon with macrophytes and floodplain. }\end{array}$ \\
\hline \multirow{2}{*}{ Vitória } & Antônia & 1 & 0.40 & 1.20 & 0.50 & 1.2 & Dense forest, without aquatic macrophytes. \\
& Rosário & 1 & 0.50 & 1.40 & 1.40 & 2.0 & Without forest, with float grasses and Typha sp. \\
\hline
\end{tabular}


infers growth from the apparent shift of modes or means in a time series of length-frequency samples (PAULY \& DAVID 1981). From estimated growth parameters $\left(\mathrm{k}\right.$ and $\mathrm{L}_{\infty}$ ), the growth curve was adjusted to data from the monthly distribution of standard length (SL).

Growth performance index $(\varphi)$ was determined using the equation proposed by PAULY \& MunRo (1984): $\varphi=\log \mathrm{k}+2 \log \mathrm{L}_{\infty}$. This equation permits the identification of a biased growth parameter estimate, and can be used only to compare the growth performance of fishes with similar shapes. Longevity was estimated using the equation proposed by TAYLOR (1958): $\mathrm{t}_{\max }=\mathrm{t}_{0}+2.996 / \mathrm{k}$. In this equation, $\mathrm{t}_{\max }$ equals longevity or maximal age, $t_{0}$ represents the theoretical age at length zero, and $\mathrm{k}$ is the growth coefficient of the Von Bertalanffy model. Estimate of the $t_{0}$ parameter was determined with aid of the empirical equation proposed by PAULY (1983), calculated as follows: $\log _{10}\left(-\mathrm{t}_{0}\right)=-0.3922-0.2752 \times \log _{10} \mathrm{~L}_{\infty}-1.038 \times \log _{10} \mathrm{k}$. The Bhattacharya method (BHATTACHARYA 1967) was used to separate the cohort and determination of the mean using the FISAT II computational package. This was done through modal progression analysis of length-frequency samples, in which the normal distribution curve, standard deviation and separation index were determined. The analysis infers that each normal distribution represents one cohort (GAYANILO JR. et al. 2005).

Total mortality (Z), defined here as equal to natural mortality (M), was calculated based on the formula proposed by PAULY (1980): $\ln (\mathrm{M})=-0.0152-0.279 \times \ln \left(\mathrm{L}_{\infty}\right)+0.6543 \times \ln (\mathrm{k})+0.463$ $\mathrm{x} \ln (\mathrm{T})$. In this equation, $\mathrm{T}$ is the annual mean water temperature in ${ }^{\circ} \mathrm{C}$. As the water surface temperature is close to air temperature, the latter was used in the equation to estimate mortality. Growth parameters ( $\mathrm{L}_{\infty}$ and $\mathrm{k}$ ) were also used in the equation.

Recruitment pattern was determined through length-frequency samples and growth parameters ( $\mathrm{L}_{\infty}$ and $\mathrm{k}$ ) estimated for the species, using a routine of the FISAT II program (GAYANILOJR \& PAUly 1997). To evaluate the effect of temporal variation on recruitment, data recruitment behavior was analyzed graphically as a function of rainfall, using Spearman's correlation test. Rainfall data was obtained from the National Meteorology Institute (INMET), measured at the Ivinhema-MS station, located approximately $7 \mathrm{~km}$ from the sampled sites.

\section{RESULTS}

A total of 933 individuals of $H$. marginatus were caught from January to December 2002 (97 in the Vitória sub-basin and 836 in the Piravevê sub-basin). Weight ranged from 0.01 to $0.89 \mathrm{~g}$ (mean $=0.26 \mathrm{~g}$; standard deviation $=0.16$ ) and standard length ranged from 8.80 to $33.0 \mathrm{~mm}$ (mean $=21.60 \mathrm{~mm}$; standard deviation $=4.67$ ) in the Piravevê sub-basin. Larger mean weight and length values were recorded in the Vitória sub-basin, with weight ranging from 0.01 to $1.08 \mathrm{~g}$ (mean = $0.63 \mathrm{~g}$; standard deviation $=0.25$ ) and length ranging from 16.2 to $35.4 \mathrm{~mm}($ mean $=29.24 \mathrm{~mm}$; standard deviation $=4.42)$.
Polymodal length frequency distribution was determined. However, distribution was asymmetric and truncated to the right side in the region of the largest lengths of both sub-basins. The Piravevê sub-basin had a higher number of individuals in the 16-to-18-mm range and the Vitória sub-basin had a higher number of individuals in the 28-to-34-mm range (Figs 2 and 3).
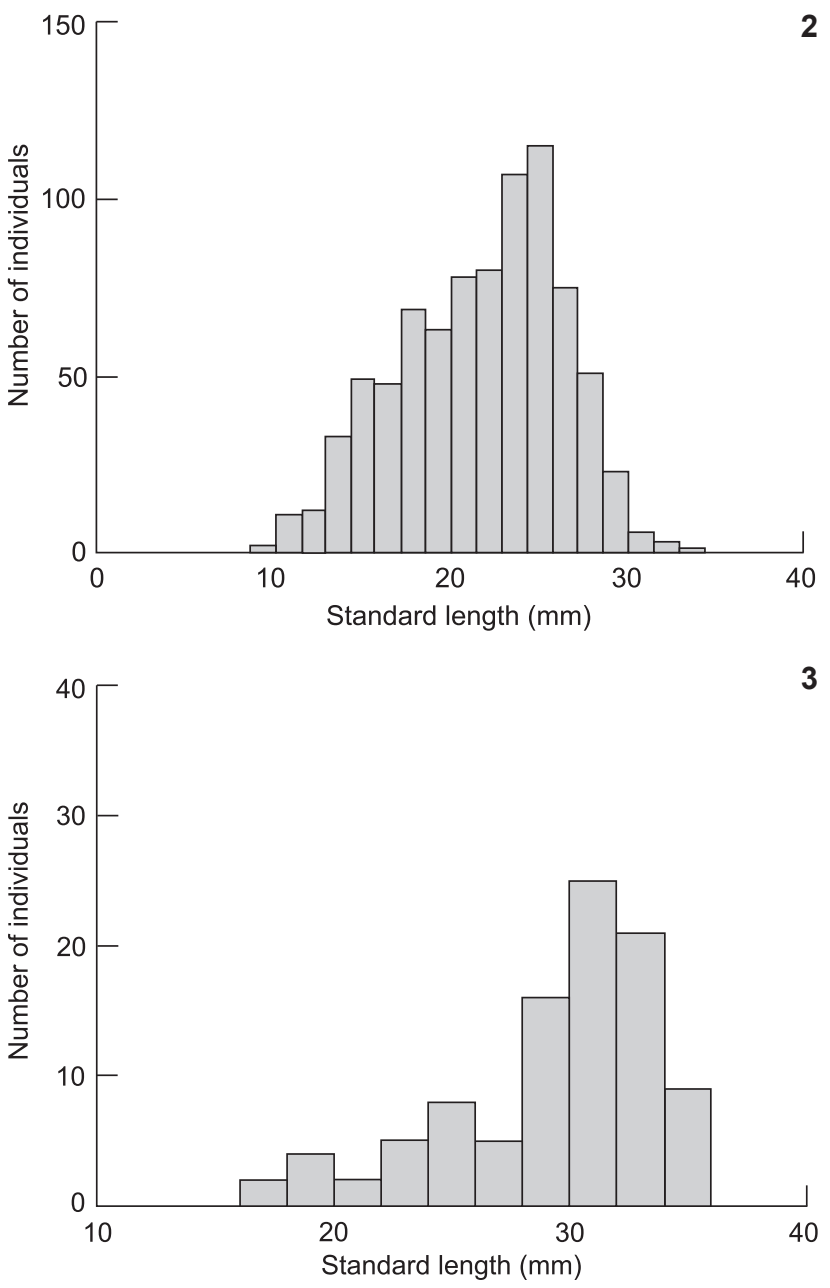

Figures 2-3. Length-frequency distributions of $H$. marginatus caught in the Piravevê sub-basin (2) and Vitoria (3), Ivinhema River basin.

ANOVA demonstrated that mean length varied between sub-basins $\left(\mathrm{F}_{1.929}=23.512, \mathrm{p}<0.001\right)$ and months $\left(\mathrm{F}_{1,929}=22.744\right.$, $\mathrm{p}<0.001)$, with no interactions between sub-basin and sampling period $\left(\mathrm{F}_{1.929}=0.619, \mathrm{p}=0.432\right)$ (Fig. 4).

The weight-length relationship determined through nonlinear regression for the two sub-basins demonstrated that the Piravevê sub-basin had the lowest value of constant "a" and the highest value of intercept " $b$ ". An overlap of the estimated pa- 


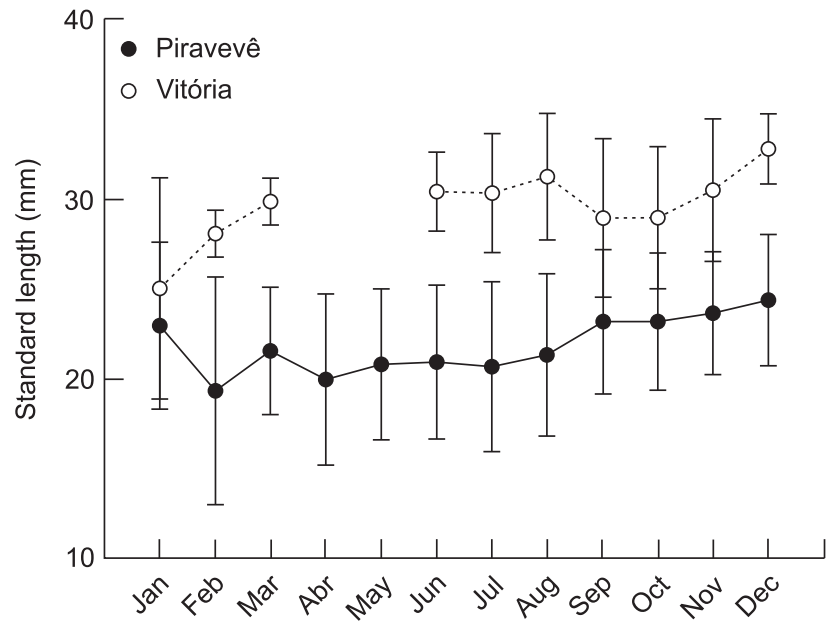

Figure 4. Mean standard length by month and sub-basin for $H$. marginatus, sampled in two sub-basins of the Ivinhema River. Vertical bar represents standard deviation of average values.

rameters ( $a$ and $b$ ), with a broader range of variation in the confidence interval, was observed in the Vitória sub-basin. These results reveal no difference in weight-length relationship of $H$. marginatus between the study sites (Tab. II, Figs 5 and 6).

Table II. Non-linear regression analysis of weight in function of standard length ( $\mathrm{SL}$ ) of individuals as the estimated values of " $a$ " and " $b$ ", as well as the confidence interval, for the streams of the Ivinhema River basin, from January to December 2002.

\begin{tabular}{cccccc}
\hline Sub-basin & $\mathrm{N}$ & $\mathrm{a}$ & $\mathrm{b}$ & $\mathrm{r}^{2}$ & $\mathrm{p}$ \\
\hline Piravevê & \multirow{2}{*}{836} & 0.000017 & 3.094 & \multirow{2}{*}{0.98} & $\mathrm{p}<0.01$ \\
& & $(0.000014-0,000020)$ & $(3.036-3.153)$ & & \\
Vitória & \multirow{2}{*}{97} & 0.000023 & 3.001 & 0.99 & $\mathrm{p}<0.01$ \\
\hline
\end{tabular}

There was no influence from temporal variation $\left(\mathrm{F}_{1.929}=\right.$ $0.448, \mathrm{p}=0.503)$ or spatial variation $\left(\mathrm{F}_{1.929}=2.002, \mathrm{p}=0.157\right)$ on the condition factor of individuals, and no interaction between these factors $\left(\mathrm{F}_{1.929}=2.963, \mathrm{p}=0.085\right)$. Graphic analysis of condition factor throughout the year in the two sub-basins demonstrated virtually constant values (Fig. 7).

Maximal length for $H$. marginatus was estimated at 37.65 $\mathrm{mm}$, with a mortality rate of 1.22 year $^{-1}$ and growth rate $(\mathrm{k})$ of 0.66 year $^{-1}$. Longevity was 4.25 years and the growth performance index was 3.80. Figure 8 displays the adjusted growth curve from the Von Bertalanffy equation. Using the modal progression method, four cohorts were calculated for the Piravevê sub-basin (Tab. III).

With regard to recruitment, there was input of individuals in the population from February to November, with the highest frequency of input between May and September. More-
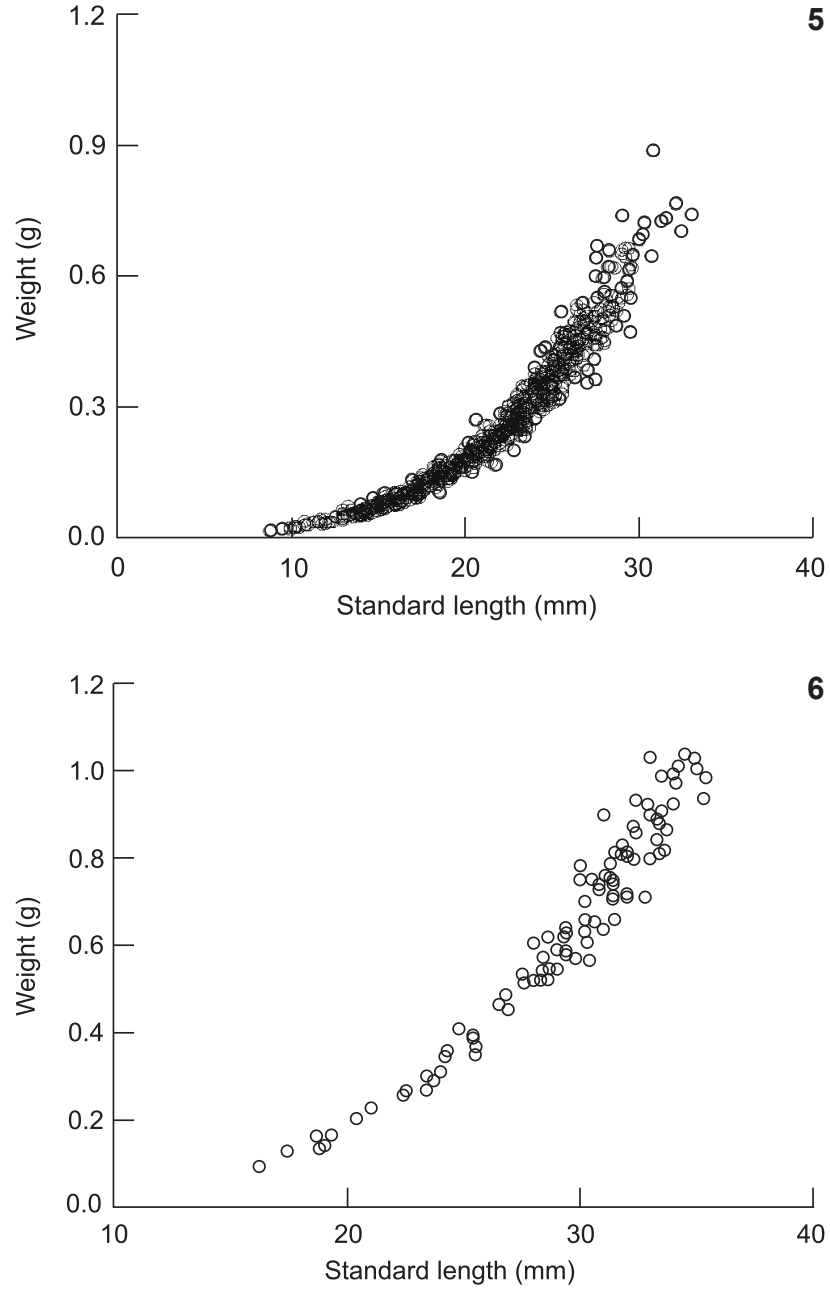

Figures 5-6. Weight/length relationship for $H$. marginatus in the Piravevê sub-basin (5) and Vitória sub-basin (6), Ivinhema River basin.

Table III. Mean, Standard deviation (SD), Number of individuals $(\mathrm{N})$, proportion of individual (Pro), and separation index (SI) of each cohort using the Bhattacharya method for population of $\mathrm{H}$. marginatus from 2002.

\begin{tabular}{cccccc}
\hline Cohorts & Mean & SD & N & Pro & SI \\
\hline 1 & 10.52 & 1.43 & 38 & 0.05 & n.a \\
2 & 15.04 & 1.36 & 155 & 0.22 & 2.29 \\
3 & 22.90 & 2.07 & 421 & 0.59 & 2.54 \\
4 & 30.68 & 2.33 & 99 & 0.14 & 2.27 \\
\hline
\end{tabular}

over, two recruitment peaks were observed - one in May, coinciding with the peak of the rainy season, and another in August, which was one of the months with the lowest amount of rainfall. Despite the recruitment peak in the period of greatest 
rainfall, the input of new recruits of $H$. marginatus occurred with a higher frequency during months with the least amount of rainfall (Fig. 9). However, no significant association was found between recruitment and rainfall $(\mathrm{r}=-0.18, \mathrm{p}=0.56)$.

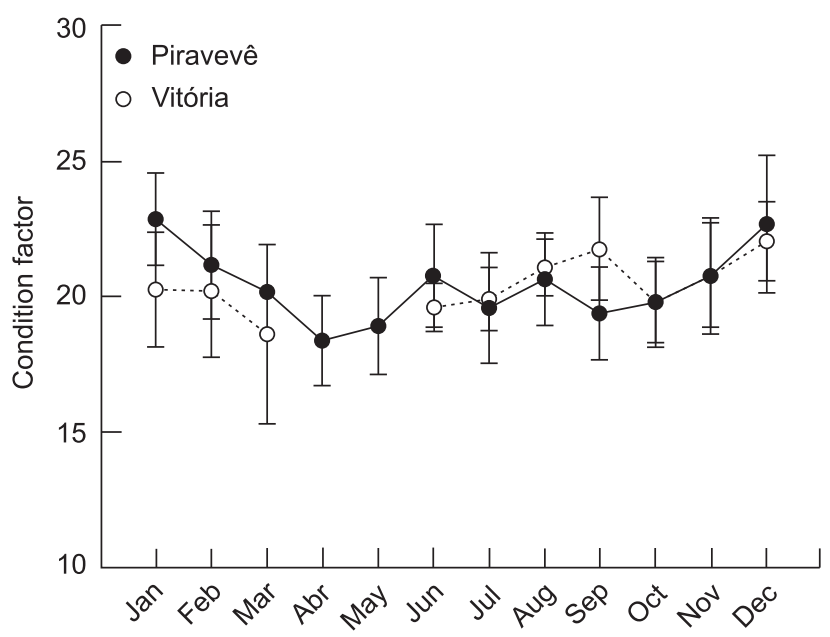

Figure 7. Mean Condition Factor by month for $H$. marginatus sampled in two sub-basins (Piravevê and Vitória) of the Ivinhema River. Vertical bar represents standard deviation of average values.

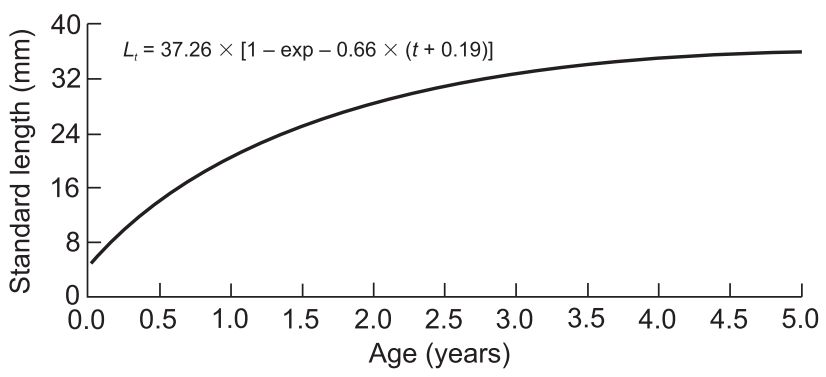

Figure 8. Length growth curve estimated for $H$. marginatus in Piravevê sub-basin, Ivinhema River Basin.

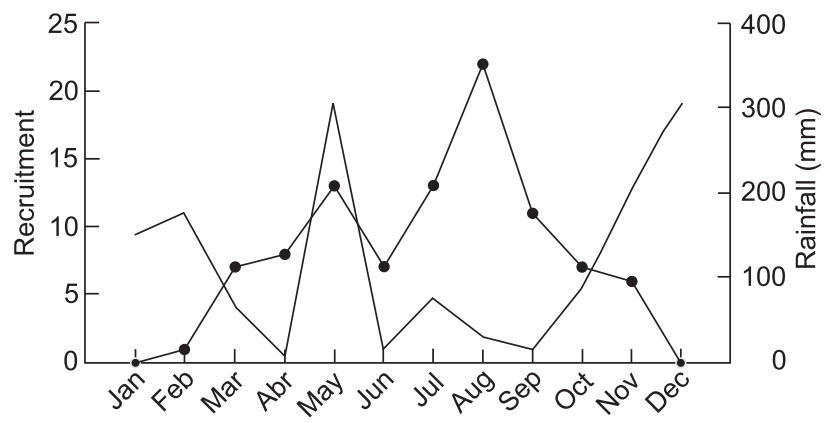

Figure 9. Recruitment pattern of $H$. marginatus and rainfall during the study period: $(\bullet)$ Recruitment, and (-) rainfall.

\section{DISCUSSION}

The length data analyzed in two sub-basins suggests spatial variation in length structure. We identified that the individuals caught in the Vitória sub-basin were, on average, smaller than those caught in the Piravevê sub-basin. This occurred because the streams are subject to short-term changes and fish populations have the capacity to adapt by adjusting some of their life history traits. Length is a life history trait that responds to local conditions (Trendall, 1982, Lowe-McConnelL 1999).

The Piravevê sub-basin has larger streams, a channel with riffles alternating with pools, and a small marginal lagoon with aquatic macrophytes (Tab. I). It is possible that the characteristics of this sub-basin allow for the occurrence of individuals in different length classes, especially juveniles. In addition, the higher frequency of smaller individuals in this sub-basin may be related to differences in habitat availability between the subbasins (Piravevê and Vitória). In the Piravevê sub-basin, a thirdorder stream was sampled (Piravevê stream), which has a large amount of submerged aquatic plants, as well as a small pond and floodplain. In contrast, no third and second-order streams were sampled in the Vitória sub-basin (Tab. I). In this context, length structure in the Piravevê sub-basin could be attributed to favorable conditions (biotic and abiotic) for the populations of these streams (GURGel 2004, Orsi et al. 2004).

On the other hand, variations in length composition between sub-basins could be explained by the differential spatial occupation of habitats in relation to specimen length. This is in function of adequate structural conditions of the environment for each life cycle stage (larvae, juveniles and adults). In the Ubatiba River, spatial segregation of length classes was reported for Astyanax janeiroensis Eigenmann, 1908 population. It was found that larger individuals were abundant in the upstream sections, and smaller juveniles were abundant in the downstream section (MAzzoni et al. 2004). This same distribution pattern was reported for Mimagoniates microlepis (Steindachner, 1877) in a coastal stream in the state of Paraná, Brazil (Braga et al. 2007).

No evidence was found of any difference in the weightlength relationship between sub-basins. The allometric equation $\left(y=a x^{b}\right)$ had been developed to describe the relative growth of various parts of the organism. An analogous formula ( $\mathrm{W}=$ a. $\mathrm{L}^{\mathrm{b}}$ ) was used to describe growth in terms of weight-length relationship, in which $\mathrm{W}$ represents individual weight, $\mathrm{L}$ represents length, a is the proportionality coefficient or condition factor, and b is the allometric coefficient. This equation is often used either to describe the increase in length and consequent weight gain, or to estimate mean weight when length is known (Braga 1996). Parameter values of the weight-length relationship for $H$. marginatus in the two sub-basins were equal, which indicates that the specimens in the two sub-basins exhibit similar weight gain and length increase. 
In sampling carried out on the right and left margins of the Paraná River Floodplain, set within secondary channels formed by the Baía River, Curutuba Channel and lower course of the Ivinhema River, weight-length relationship parameters for $H$. marginatus were: $\mathrm{a}=0.01450$ and $\mathrm{b}=3.14$ (LizAmA \& Aмвrósio 1999). In the two sub-basins of the Ivinhema River, the constant estimated value was much lower $(a=0.0000203)$, but the increase in body length was similar $(b=3.040)$ to that found in the upper Paraná River. Thus, one may conclude that the H. marginatus population in the floodplain of the Paraná River has greater weight gain than the population in the Ivinhema River Basin, while the increase in length is similar in both sites.

The growth parameters estimated for the species in the Piravevê sub-basin follow a predictable pattern, as species of small size, which are considered prey, are expected to exhibit fast growth, high mortality rate and, consequently, low longevity values (WооттоN 1999). The growth parameter estimates for small-sized species in the Ivinhema River basin follow this same pattern (LouRenço et al. 2008). A similar pattern was also reported for the Moenkhausia dichroura (Kner, 1858) population sampled in an oxbow lake located on the right margin of the Aquidauana River in the Patanal Wetland (Brazil) (CunHa et al. 2007).

The growth performance estimate $(\varphi)$ for the species was 3.80 , which is close to estimates reported for other species of the same family, such as Serrapinnus notomelas (Eigenmann, 1915) $(\varphi=3.027)$, Bryconamericus stramineus Eigenmann, 1908 ( $\varphi=3.208)$ (Lourenço et al. 2008), Roeboides paranensis Pignalberi, 1975 ( $\varphi=3.64)$ (CAPISTRANO-SANTANA et al. 2004), and M. dichroura ( $\varphi=3.75$ ) (CunHA et al. 2007). Estimation of growth and asymptotic length using the same model permits the comparison of performance among fishes with similar shapes (Mateus \& Penha 2007). Broad variation in this value indicates an error in the estimate of growth parameters. Therefore, the value reported in the present study for $H$. marginatus suggests a good estimate of parameters, as there was no large difference in comparison to other species of the same family.

Length-frequency analysis is based on the supposition of seasonal recruitment with one or two peaks throughout the year at most (Sparre \& Venema 1997). There are two input peaks of individuals in the $H$. marginatus population throughout the year - one in the dry season (greater) and another in the wet season (lesser). These findings suggest more than one reproductive event throughout the year, with apparently greater recruitment frequency during months of lesser rainfall. However, there is no evidence of a negative correlation between recruitment and months with greater rainfall. This pattern of high degree of recruitment in the dry season among small-sized fishes is also reported for B. stramineus and S. notomelas in streams of the Ivinhema River Basin (Lourenço et al. 2008), as well as for S. notomelas in the Dourados River Basin of the upper Paraná River (Benitez \& Súarez 2009). The 'low flow recruitment hy- pothesis' postulates that some species of fishes take advantage of extended recruitment in the dry season because of concentrations in appropriately sized prey. Lesser volume of water would concentrate the prey to such an extent that could increase densities to levels sufficient to feed larvae (Humphries et al. 1999).

The explanation for more than one reproductive event and input of individuals in the $H$. marginatus population may be related to the opportunistic reproductive strategy of smallsized species of fishes in the Neotropical region (WINEmilLeR 1989, Lowe-McConnell 1999). Species exhibiting this strategy maximize the colonization capacity of environments that undergo unpredictable changes in time and space (WINEMILLER 1989, Lowe-McConnell 1999). Essentially, juveniles resulting from more than one reproductive episode in a given year perform the task of colonization (WoOTTON 1999). This constitutes an advantage for such species, as small fishes are unable to store large amounts of oocytes (LAMPERT et al. 2007). In the Ubatiba River, Astyanax janeiroensis reportedly breeds practically throughout the entire year, except in May and June, with greater reproduction intensity between November and March (Mazzoni et al. 2005). In a coastal stream of the Atlantic Forest, specimens of Bryconamericus microcephalus (Miranda Ribeiro, 1908) were found in reproductive condition between June and February, with peak breeding between September and December (MAZZoni \& Silva 2006).

The condition factor is an index used in studies on fish biology that indicates the nutritional status of fishes, resulting from the interaction of biotic and abiotic factors. This measure is generally used when the intention is to: (I) compare two or more populations under different conditions; (II) determine the duration of the reproductive period; and (III) determine the degree of feeding activity (Braga 1986, Braga 1993). However, no spatial (between sub-basins) or temporal (throughout the year) variations in the condition factor were found in the present study, suggesting similar physiologic conditions of individuals in both sub-basins.

The H. marginatus population demonstrated high growth and mortality rates as well as a relatively high longevity value. Yet this longevity value is still considered low in comparison to the longevity of long-living species of fishes. This species exhibited recruitment occurring twice throughout the year once in the dry season and once in the wet season. These features characterize the reproductive strategy of this species as opportunistic.

\section{ACKNOWLEDGMENTS}

The authors are grateful to the Universidade Estadual do Mato Grosso do Sul, for financial support. Further thanks goes to the following Brazilian fostering agencies: Coordenação de Aperfeiçoamento de Pessoal de Nível Superior for the scholarship awarded to LSL; and Conselho Nacional de Desenvolvi- 
mento Científíco e Tecnológico for the scholarship awarded to IMF, as well as for productivity grants given to YRS. We are grateful to Ursulla P. de Souza for reviewing the manuscript.

\section{LITERATURE CITED}

Andrade, V.X.L.; F.F.S. Campos; F. Langeani \& E. Romagosa. 2008. Reproductive dynamics of the main species of fish in the municipal reservoir of São José do Rio Preto. Boletim do Instituo Pesca 34 (3): 365-373.

Benitez, R.S. \& Y.R. Súarez. 2009. Biologia populacional de Serrapinnus notomelas (Eingenmann, 1915) (Characiformes, Cheirodontinae) em um riacho de primeira ordem na bacia do rio Dourados, Alto rio Paraná. Pan-American Journal Aquatic Science 4 (3): 271-278.

Bhattacharya, C.G. 1967. A simple method of resolution of distribution Gaussian components. Biometrics 23 (1): 115135.

BRAGA, F.M.S. 1986. Estudo entre Fator de Condição e relação peso/comprimento para alguns peixes marinhos. Revista Brasileira de Biologia 46 (2): 339-346.

BRAGA, F.M.S. 1993. Análise do fator de condição de Paralonchurus brasiliensis (Perciformes, Scianidae). Revista UNIMAR 15 (2): 99-115.

BRAGA, F.M.S. 1996. Análise da equação alométrica na relação peso/comprimento e o fator de condição em Plagioscion squamosissimus (Teleostei, Scianidae). Revista Brasileira de Biologia 57 (3): 417-425.

Braga, M.R.; J.R.S. Vitule \& J.M.R. Aranha. 2007. Estrutura populacional de Mimagoniates microlepis (Steindachner, 1876) (Characidae, Glandulocaudinae) em um riacho de Floresta Atlântica, Paraná (Brasil). Acta Biológica Paranaense 36 (1-2): 67-81.

CAmpana, S.E. 2001. Accuracy, precision and quality control in age determination, including a review of the use and abuse of age validation methods. Journal of Fish Biology 59 (2): 197-242. doi: 10.1111/j.1095-8649.2001.tb00127.x.

Capistrano-Santana, A.C.; R.S. Almeida; R.W. Ávila \& A.C. Catella. 2004. Estimativa dos parâmetros de crescimento de Roeboides paranensis: diferentes respostas para uma mesma pergunta. In: IV Simpóso sobre Recursos Naturais e Sócio-econômicos do Pantanal - Sustentabilidade Regional, Corumbá, Embrapa Pantanal, [CD-ROM].

Casatti, L.; H.F. Mendes \& K.M. Ferreira. 2003. Aquatic macrophytes as feeding site for small fishes in the Rosana reservoir, Paranapanema river, Southeastern Brazil. Brazilian Journal of Biology 63 (2): 213-222. doi: 10.1590/S151969842003000200006.

Cunha, N.L.; A.C. Catella \& M.A. Kinas. 2007. Growth parameters estimates for a small fish of the Pantanal, Brazil: Moenkhausia dichroura (Characiformes; Characidae). Brazilian Journal of Biology 67 (2): 293-297. doi: 10.1590/S151969842007000200014 .
De Angelis, D.L.; K.A. Rose; L.B. Crowder; E.A. Marschall \& D. Lika. 1993. Fish cohort dynamics: Application of complementary modeling approaches. American Naturalist 142 (4): 604-622.

Gayanilo-JR, F.C. \& D. Pauly. 1997. The FAO-IClarm Stock Assessment Tools (FISAT) Reference manual. FAO Computerized Information Series (Fisheries) 8:1-196.

Gayanilo-Jr, F.C.; P. Sparre \& D. Pauly. 2005. The FAO-IClarm Stock Assessment Tools (FISAT II) User's guide. FAO Computerized Information Series (Fisheries) 8: 1-168.

Gorman, O.T. \& J.R. KarR. 1978. Habitat Structure and Stream Fish Communities. Ecology 59 (3): 507-515.

Grabowski, T.B. \& J.J. Isely. 2008. Size of spawning population, residence time, and territory shifts of individuals in the spawning aggregation of a riverine Catostomid. Southeastern Naturalist 7 (3): 475-482.

Gurgel, H.C.B. 2004. Estrutura populacional e época de reprodução de Astyanax fasciatus (Curvier) (Characidae, Tetragonopterinae) do Rio Ceará Mirim, Poço Branco, Rio Grande do Norte, Brasil. Revista Brasileira Zoologia 21 (1): 131-135.

Humphries P.; A.J. King \& J.D. Koenn. 1999. Fish, Flows and Flood Plains: Links between Freshwater Fishes and their Environment in the Murray-Darling River System, Australia. Environmental Biology of Fishes 56 (1-2): 129-151.

Instituto Nacional de Meteorologia. 2012. Available online at: www.inmet.gov.br [Accessed: 12/IV/2012].

Lampert, V.R.; M.A. Azevedo \& C.B. Fialho. 2007. Reproductive biology of Bryconamericus stramineus Eigenmann, 1908 (Ostariophysi: Characidae) from the Rio Ibicuí, RS, Brazil. Brazilian Archives of Biology and Technology 50 (6):995-1004.

LizAma, M.A.P. \& A.M. Ambrósı́. 1999. Relação peso-comprimento e estrutura da população de nove espécies de Characidae na planície de inundação do Alto Rio Paraná, Brasil. Revista Brasileira de Zoologia 16 (3): 779-788.

Lourenço, L.S.; Y.R. SuARez \& A.C. Florentino. 2008. Aspectos populacionais de Serrapinnus notomelas (Eigenmann, 1915) e Bryconamericus stramineus Eigenmann, 1908 (Characiformes: Characidae) em riachos da bacia do rio Ivinhema, Alto Rio Paraná. Biota Neotropica 8 (4): 43-49.

Lowe-McConnell, R. H. 1999. Estudos ecológicos de comunidades de peixes tropicais. São Paulo, EDUSP, 535p.

Mateus, L.A.F. \& J.M.F Penha. 2007. Dinâmica populacional de quatro espécies de grandes bagres na bacia do rio Cuiabá, Pantanal norte, Brasil (Siluriformes, Pimelodidae). Revista Brasileira de Zoologia 24 (1): 87-98. doi: 10.1590/S010181752007000100012.

Mazzoni, R. \& A.P.F. Silva. 2006. Aspectos de história de vida de Bryconamericus microcephalus (Miranda Ribeiro) (Characiformes, Characidae) de um riacho costeiro de Mata Atlântica, Ilha Grande, Rio de Janeiro, Brasil. Revista Brasileira de Zoologia 23 (1): 228-233. doi: 10.1590/S0101-81752006000100016.

Mazzoni, R.; R.S. Mendonça \& E.P. Caramaschi. 2005. Reproductive Biology of Astyanax Janeiroensis (Osteichthyes, Characidae) from the Ubatiba river, Maricá, RJ, Brazil. Brazilian Journal 
of Biology 65 (4): 643-649. doi: 10.1590/S1519-69842005000 400012.

Mazzoni, R.; S.A. Schubart \& R. Iglesias-Rios. 2004. Longitudinal segregation of Astyanax janeiroensis in Rio Ubatiba: a Neotropical stream of south-east Brazil. Ecology of Freshwater Fish 13 (3): 231-234. doi: 10.1111/j.1600-0633.2004.00062.x.

Nikolsky, G.V. 1963. The Ecology of Fishes. New York, Academic Press, 352p.

Orsi, M.L.; E.D. Carvalho \& F. Foresti. 2004. Biologia Populacional de Astyanax altiparanae Garutti \&Britski (Teleostei, Characidae) do Médio Rio Paranapanema, Paraná, Brasil. Revista Brasileira de Zoologia 21 (2): 207-218.

Pauly, D. \& J.L. MunRo. 1984. Once more on the comparison of growth in fish and invertebrates. ICLARM Fishbyte 2 (1): 1-21.

Pauly, D. \& N. DAVID. 1981. ELEFAN I, a BASIC programme for the objective extraction of growth parameters from length frequencies data. Meeresforschung 28 (4): 205-211.

Pauly, D. 1980. On the interrelationships between natural mortality, growth parameters and mean environmental temperature in 175 fish stock. International Council Exploration of the Sea 39 (2): 175-192.

Pauly, D. 1983. Some simple methods for the assessment of tropical fish stocks. FAO Fish. Technical Paper 234: 1-52.

Reis, R.E.; O. Kullander \& C.J. Ferraris Jr. 2003. Check List of the Freshwater Fishes of South and Central America. Porto Alegre, EDIPUCRS, 729p.

Reznick, D.N.; M.J. ButLer; F.H. Rodd \& P. Ross. 1996. Life-History
Evolution in guppies (Poecilia reticulate) 6. Differential Mortality as a Mechanism for natural Selection. Evolution 50 (4): 1651-1660.

Souza-Filho, E.E. \& J.C. Stevaux. 2004. Geology and geomorphology of the Baía-Curutuba- Ivinhema River Complex. p. 1-29. In: S.M. Thomaz; A.A. Agostinho \& N.S. Hahn (Eds). The Upper Paraná River and its Floodplain: Physical aspects, Ecology and Conservation. Leiden, Backhuys Publishers, I+415p.

SPARRE, P. \& S.C. VENEMA. 1997. Introdução à avaliação de mananciais de peixes tropicais. Parte 1: Manual. Roma, FAO, 404p.

SúAREZ, Y.R. 2008. Variação espacial e temporal na diversidade e composição de espécies de peixes em riachos da bacia do Rio Ivinhema, Alto Rio Paraná. Biota Neotropica 8 (3): 197-204.

TAYLOR, C.C. 1958. Cod growth and temperature. Journal du Conseil International pour l'Exploration de la Mer 23 (3): $366-370$.

Trendall, J.T. 1982. Covariation of Life History Traits in the Mosquitofish, Gambusia affinis. The American Naturalist 119 (6): 774-783.

WinemiLLer, K.O. 1989. Patterns of variation in life history among South American fishes in seasonal environments. Oecologia 81 (2): 225-241.

Wootton, R. 1999. Ecology of Teleost Fishes. London, Chapman \& Hall, $2^{\text {nd }}$ ed., $416 \mathrm{p}$.

WOOTTON, R.; J.B. ELVIRA \& J.A. BAKER. 2000. Life-history evolution, biology and conservation of stream fish: introductory note. Ecology of Freshwater Fish 9 (1-2): 90-91.

Submitted: 01.VI.2011; Accepted: 15.V.2012.

Editorial responsibility: Wolmar B. Wosiacki 